\title{
REGIONAL ANALYSIS OF THE PACIFIC ALLIANCE COUNTRIES ON THE RELATIONSHIP BETWEEN INCOME INEQUALITY AND SOCIAL CAPITAL
}

Original scientific paper

UDK: $330.564+330.14: 316]: 339.92$

JEL classification: A13; D31; R11

DOI: 10.17818/DIEM/2022/1.1

Accepted for publishing: July 8, 2021

\begin{abstract}
Social capital is considered a productive resource for societies. The increase in social trust is usually related to both economic growth and a reduction in inequality. In Latin American countries, and particularly the economies that belong to the Pacific Alliance, the relationship between social capital and income inequalities has not been studied at regional level. The paper aims to analyze whether social capital impacts income inequality in the case of the Pacific Alliance regions. Dynamic panel data models were used, covering 72 regions during the period 2002-2011. The results show that the decline in generalized trust and congress trust impacts negatively income inequality, while government trust, police trust and company trust have not effect.
\end{abstract}

Keywords: social capital, inequalities, dynamic panel model, Latin America

\section{INTRODUCTION}

The theory of capital is increasingly relevant in regional studies (Borozan and Funaric, 2016; Bengoa, Román and Pérez, 2017). In particular, through cooperation in collective actions and participation in decision-making, an increase in generalized and institutional trust should act as a means of reducing economic inequality (Knack and Keefer, 1997; Putnam, 2000; Ram, 2012; Wang and Lu, 2016).

In the Pacific Alliance countries, social capital is unevenly distributed, with a low contribution to the economy, because different actions have been taken and with little importance to the implementation of social policies that help increase social capital. In recent years, the disparate levels of social trust have been an intrinsic problem in the Latin economies, thus contributing to the presence of wage gaps between the highest and the lowest deciles (Kliksberg, 1999).

Based on the results of income distribution at a regional and country level, our attention is drawn to analyzing whether advances in social capital reduce intraregional income inequality for the regions of the countries that belong to the Pacific Alliance. The research question arises due to 
the fact, shown by Putnam (2000), that the societies which present a higher rate of participation in networks, civic norms and trust, have economic equality within the members of a society, on the contrary, if they lack this resource, income inequalities will be persistent.

This research analyzes whether intraregional economic equality is favored by social trust in the regions of the countries that belong to the Pacific Alliance.

In the literature review, it was found that there is no study that analyzes this relationship between the variables using regional data from the economies with the highest income inequality worldwide, which is relevant, since there is heterogeneity among the regions of the Pacific Alliance.

This study differs from current research on several points. Firstly, we use a database extracted from the Latinobarómetro survey during the period from 2002 to $2011^{1}$. We consider that collective social capital refers to the degree to which people trust other members of society (Putnam, 2000) and that all forms of cognitive social capital influence income inequalities (Rothstein and Uslaner, 2006). Secondly, 72 regions of Chile, Colombia, Mexico and Peru were analyzed, these economies are in the most unequal region in the world. Thirdly, in order to treat endogeneity problems between variables, the dynamic panel data models proposed by Roodman (2009) are used. The use of this estimator, unlike the generalized method of moments estimators of difference and system proposed by Arellano and Bond (1991) and Arellano and Bover (1995), allows us to analyze the limited time span and the potential of fixed and endogenous regressors among the variables of the model.

\section{LITERATURE REVIEW}

This section presents the relationship between the variables and the context of the Pacific Alliance countries, related to our object of study

\subsection{Relationship between social capital and income inequalities}

Over the last few years, recent research has studied how inequalities of opportunities, inequalities of resources and economic inequalities affect the formation of social capital (Kliksberg, 1999; Elgar and Aitken, 2011; Stephany, 2017). However, few studies research the impact of the decline in intraregional social capital in developing countries on income disparities among members of a society.

From the perspective of Banfield (1958) and the studies carried out by Putnam (1993, 2000), the negative effect of societies is observed when citizens have minimal or no involvement in what happens in their environment, that is to say; citizens show reluctance to share, to receive and provide help, as a result, transactions decrease and there is no mutual benefit; therefore, the resource of social capital does not act as a means in reducing social problems, such as poverty, income inequalities and economic growth (Robison, Siles and Schmid, 2003; Woolcock, 2010).

Knack and Keefer (1997) have demonstrated the importance of trust and civic norms as forms of social capital in aggregate economic activity within 29 economies. Finding that economies with low interpersonal trust create the perfect scenarios for the increase in economic inequalities among members of a society.

This also happens in the context of Latin American countries, low social trust and the increase in income inequality are the result of the deficient involvement of the State in the

\footnotetext{
${ }^{1}$ This analysis period was considered due to the limited availability of regional data for the Pacific Alliance countries. In the case of capital stock, the data is available until 2020, however, this does not apply for the intra-regional gini index; since the data are scarce and not periodic. Although, the imputation of missing data is applied, it was not feasible to impute data until the current period, because the estimates would lack veracity.
} 
generation of policies that allow the development of social cohesion and generalized trust (Gallicchio, 2004; Güemes, 2011). Taking into account the importance of trust as a form of social capital, studies recognize the relevance of this type of capital as the prerequisite for the performance of cooperation and collective actions (Schaik, 2002).

The literature argues that trust has been shown to have a positive correlation with economic equality (Knack and Keefer, 1997; Stiglitz, 2012; Bergh and Bjørnskov, 2014; Bolaños, Saucedo-Acosta and Del Callejo, 2021). This is the case in countries such as: Norway, the Netherlands and Canada, etc. where they have the highest indices of generalized trust and economic equality (Wilkinson and Pickett, 2009). Although, in developing countries, as in the case of Latin American countries, the situation is different. We believe that there is heterogeneity and little social trust and that this has generated low cooperation from the members of a society with regard to collective action problems, which permeates income inequalities

\subsection{Social capital in Pacific Alliance Countries}

The Pacific Alliance is a trade bloc initiative of the American continent, which was established in 2011, with four economies: Colombia, Chile, Mexico and Peru (see figure 1).

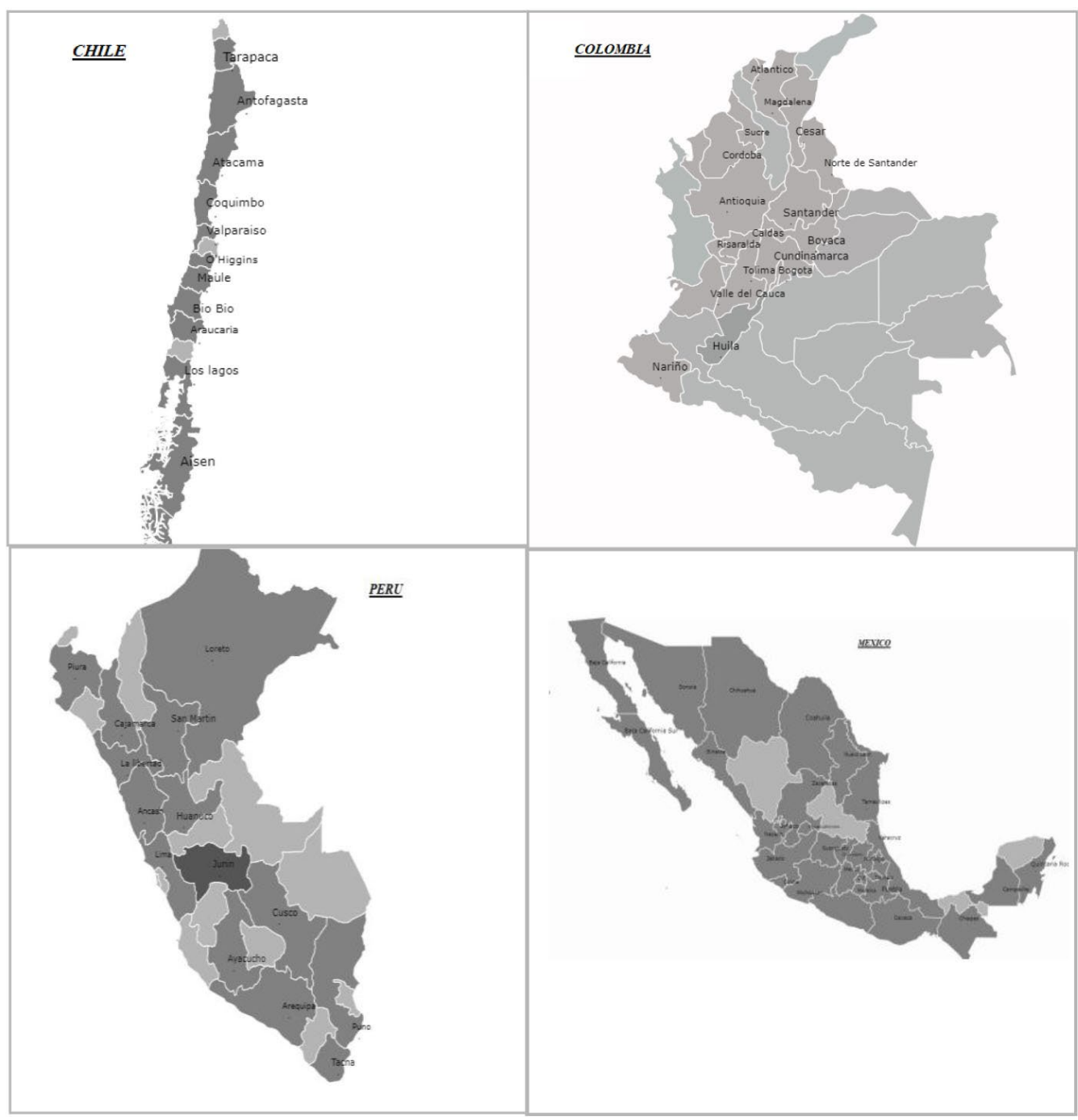

Source: elaborated by authors

Figure 1 Pacific Alliance Countries 
With regard to the distribution of social capital, Latin America has shown to have low levels of generalized trust compared to developed countries (Barone and Mocetti, 2016; Lee and Law, 2017). The Latin American economies have gone through different transition processes in terms of social policy, since the eighties social issues have been put aside as a consequence of the debt crisis that most of the countries were experiencing. Later, in the nineties, social policy took on a renewed importance in economies, regaining the relevance of action in social issues, poverty, systems of reciprocity and social capital (Arriagada, 2005; Hardy, 2003)

Although various studies have been carried out that prove the impact of this resource for developed and developing societies (Glanville, Paxton and Wang, 2016; Jhonh F et al., 2017), in the case of Latin America, the programs to increase this resource have been unsuccessful. In particular, for the year $200018.4 \%$ of the population in the Pacific Alliance countries consider that people are trustworthy, whereas for the year 2016 only $18.1 \%$ trust people in general (Latinobanometro, 2019)

\section{METHOD AND DATA}

The following equations represent the estimators proposed by Arellano and Arellano and Bover, (1995):

$$
\begin{gathered}
Y_{i t}=\propto Y_{i, t-1}+\beta X^{\prime}+\varepsilon_{i t} \\
\varepsilon_{i t}=\mu_{i}+\vartheta_{i t} \\
E\left(\mu_{i}\right)=E\left(\vartheta_{i t}\right)=E\left(\mu_{i} \vartheta_{i t}\right)=0
\end{gathered}
$$

Therefore, we represent the following equation for our object of study:

$$
\begin{aligned}
& G_{i n i_{i t}}=\alpha G i n i_{i, t-1}+\beta_{1} G T_{i t}+\beta_{2} J T_{i t}+\beta_{3} C T_{i t}+\beta_{4} G o T_{i t}+ \\
& \beta_{5} P T_{i t}+\beta_{6} G D P_{-i, t}+\varepsilon_{i t}
\end{aligned}
$$

The equation (4) expresses that income inequality ( $\left(\mathrm{Gini}_{\mathrm{it}}\right)$ depends on the lagged variable $\left(\right.$ Gini $\left._{i, t-1}\right)$; a set of social capital variables: generalized trust (Gentrust $\left.\mathrm{i}_{i, t}\right)$, judiciary trust (Judtrust $\mathrm{i}_{\mathrm{i}, \mathrm{t}}$ ), congress trust (Congtrust $\mathrm{i}_{i, \mathrm{t}}$ ), government trust (Govertrust $\mathrm{t}_{\mathrm{i}, \mathrm{t}}$ ), police trust (Politrust $\mathrm{t}_{\mathrm{i}, \mathrm{t}}$ ) and Gross Domestic Product per capita (GDP_PC i,t) as a control variable.

The System GMM estimator was used instead of the difference equations proposed by Arellano and Bond, (1991). It was chosen because the equations in levels provide greater precision in the estimates when the dependent variable is persistent (Blundell and Bond, 2000). The System GMM estimation was applied through the xtabon2 command with the Stata version 14b software, proposed by Roodman, (2006). This estimator is based on the analysis of Arellano and Bond, (1991) and Arellano and Bover, (1995). However, what allows greater efficiency in this estimator is that it considers a finite sample modification for the two-stage covariance matrix, which results in the efficiency of two-step rather than one-step robustness. In this analysis, the Hansen test and the Auto correlation test were applied and one-unit root was obtained.

\subsection{Data}

The main aim of the study is to analyze the relationship between income inequality and intraregional cognitive social capital. In this study, we analyzed 72 regions of the Pacific Alliance countries: Mexico, Colombia, Peru, and Chile

Table 1 show the study variables, and data sources. In this analysis, we use the Gini index, as a dependent variable, cognitive social capital as an independent variable, and GDP per capita as a control variable. Missing data were obtained by multiple and simple imputation. First, an imputation using the regression model was implemented for the regions that presented a monotonous pattern of data and few missing data, for which a simple imputation was first carried 
out for a certain region (Cañizares, Barroso and Alfonso, 2004) and a multiple imputation by country was subsequently applied to preserve the variability of the data proposed by Honaker and King (2010).

Table 1 Study variables

\begin{tabular}{|c|c|c|}
\hline \multicolumn{3}{|l|}{ Dependent variable } \\
\hline Variable name & Description & Data source \\
\hline The regional Gini index & $\begin{array}{l}\text { Distribution of income in the family } \\
\text { market }\end{array}$ & $\begin{array}{l}\text { The official nationals statistical } \\
\text { databases (CONEVAL, 2019; DANE, } \\
\text { 2019; INEGI, 2019; MDSF, 2019). }\end{array}$ \\
\hline \multicolumn{3}{|l|}{ Independent variables } \\
\hline Generalized trust & Percent of trust between people & Latinobarometro (2019 \\
\hline Institutional trust & $\begin{array}{l}\text { Percent of trust in the congress; trust } \\
\text { in the Company; trust government } \\
\text { and trust in the Political }\end{array}$ & \\
\hline \multicolumn{3}{|l|}{ Control variables } \\
\hline GDP_percapita & $\begin{array}{l}\text { Gross domestic product converted to } \\
\text { international dollars using }\end{array}$ & $\begin{array}{l}\text { The official nationals statistical } \\
\text { databases (The regional observatory, } \\
\text { 2018; DANE, 2019; INEGI, 2019; INEI, } \\
\text { 2019; OCDE, 2019). }\end{array}$ \\
\hline
\end{tabular}

Source: elaborated by authors.

\section{RESULTS}

A dynamic panel model was run and table 2 shows the effect of different types of social capital and inequality (Gini index) where GDP was included as a control variable. The results indicate that generalized trust negatively affects the Gini index. Furthermore, the coefficient of generalized trust is negative $(-0.025)$ and significant at $5 \%$.

Diagnostic tests were included. The Wald test shows that the model is correctly estimated. The instruments (48) are inferior to groups (72), meaning that the model does not show overidentification problems. The Hansen test shows a prob $>$ chi2 $=0.436$, which indicates that the instruments used are valid. The Sargan test shows a prob $>$ chi2 $=0.861$ which also indicates that the instruments are valid.

Table 2 Inequality and social capital: Generalized Method of Moments (GMM) Estimation.

\begin{tabular}{l|l}
\hline \multicolumn{2}{l}{ Dependent Variable: Gini index } \\
\hline Variable & $0.962^{* * *}$ \\
Lag (1) Gini & $-0.024^{*}$ \\
Generalized Trust & 0.0015 \\
Company Trust & $-0.032^{*}$ \\
Congress Trust & 0.014 \\
Government Trust & -0.003 \\
Political Trust & -0.000 \\
GDP_pc & 41.79 \\
Hansen test & $-5.84^{* * *}$ \\
Arellano-Bond AR (1) & 2.39 \\
Arellano-Bond AR (2) & 31.39 \\
Sargan test & $1081^{* * *}$ \\
Wald X & 648 \\
Observations & 72 \\
Regions & \\
\hline
\end{tabular}

Notes: The Gini index is used as the independent variable. This table shows the generalized method of moments (GMM) estimation. ${ }^{* * *},{ }^{* *}$, and ${ }^{*}$ represents statistical significance at the $1 \%, 5 \%$, and $10 \%$ levels, respectively. 


\section{DISCUSSIONS AND CONCLUSIONS}

The objective of the article was to quantify the relationship between social capital and income inequality in the regions of the countries that belong to the Pacific Alliance. Members of the Pacific Alliance have historically had pro-market governments, which has had an impact on the high levels of inequality. The proposed objectives are related to the results because, through a dynamic panel data model, the relationship between social capital and inequality was estimated for the regions of the Pacific Alliance countries.

The coefficients of generalized trust and congress trust are negative and significant, which indicates that they negatively affect income inequality. The findings show that generalized trust is low for all regions, therefore, it is considered that transactions are difficult and there are coordination and cooperation problems between people, which impacts on the increase in economic inequalities.

These findings are in line with our position on the existence of the inversely proportional relationship between the variables and are similar to the presented by Knack and Keefer (1997), as these authors argue that the decrease in trust and civic norms have a negative relationship with wages, generating wage gaps. Unlike our study, the authors apply their research across countries using simple regression analysis. New research confirms our argument (Ram, 2012; Hoyman et al., 2016). Our findings do not coincide with the researches that consider no relationship between the variables (Leigh et al., 2006; Geys and Murdoch, 2008).

In the case of congress trust, this has been considered a political, fragmented and de facto system where: a) decision-making processes prevail for the executive powers, with the legislative and judicial powers having less relevance in decision-making, b) citizens consider that policy makers serve public opinion poorly, c) members of the executive powers have been involved in corruption scandals, d) Most members of Congress are made up of an elite group, whose predominance is the fulfillment of the interests of an exclusive group. These actions are relevant to citizens' low trust in Congress (Joignant, 2011; Milanese, 2011; Dargent and Muñoz, 2012). In this sense, research has shown that despite the fact some Latin American countries have grown, inequalities in the territory are increasingly visible.

The results obtained are new for two reasons: firstly, the relationship between social capital and intra-regional inequality is analyzed in a supranational region of Latin America through a panel data model; secondly, the previous relationship is studied in a process of integration such as the Pacific Alliance, which has been characterized by pro-market governments open to trade, with high levels of inequality.

The findings achieved can be useful for the governments of the Pacific Alliance, since it is shown that generalized trust and trust in congress are the forms of cognitive social capital that influence income inequalities, this is relevant for the development of public policies that encourage social capital at the regional level. On the other hand, being an intra-regional study of the Pacific Alliance, the results can be considered as input for the design of supranational public policies that aim to reduce intra-regional inequalities.

\section{REFERENCES}

Ahn, E.O.Y.T.K., 2003. Una perspectiva del capital social desde las ciencias sociales: capital social y acción colectiva*. Revista Mexicana de Sociología, [online] 50(812), pp.155-233. Available at: <http://www.scielo. org.mx/pdf/rms/v65n1/v65n1a5.pdf>. https://doi.org/10.2307/3541518

Arellano, M. and Bond, S., 1991. Some Tests of Specification for Panel Carlo Application to Data : Evidence and an Employment Equations. The Review of Economic Studies, [online] 58(2), pp.277-297. Available at: <http://www.jstor.org/stable/2297968>. https://doi.org/10.2307/2297968 
Arellano, M. and Bover, O., 1995. Another look at the instrumental variable estimation of error-components models. Journal of Econometrics, [online] 68, pp.29-51. Available at: <https://www.cemfi.es/ arellano/arellano-bover-1995.pdf >. https://doi.org/10.1016/0304-4076(94)01642-D

Arriagada, I., 2005. Aprender de la experiencia. El capital social en la superación de la pobreza. [online] Santiago de Chile: Comisión Económica para América Latina y el Caribe. Available at: <https://repositorio. cepal.org/bitstream/handle/11362/2422/S055306_es.pdf>.

Atria, R., Siles, M., Arriagada, l., Robison, L. and Whiteford, S., 2003. Capital social y reducción de la pobreza en América Latina y el Caribe: en busca de un nuevo paradigma. Santiago de Chile: Comisión Económica para América Latina y el Caribe.

Banfield's, E., 1958. The moral basis of a backward society. United State of America. https://doi.org/10.2307/2550413

Barone, G. and Mocetti, S., 2016. Inequality and trust: New evidence from panel data. Economic Inquiry, [online] 54(2), pp.794-809. Available at: <https://onlinelibrary.wiley.com/doi/abs/10.1111/ecin.12309>. https://doi.org/10.1111/ecin.12309

Bengoa, M., Román, V.M. and Pérez, P., 2017. Do R \& D activities matter for productivity ? A regional spatial approach assessing the role of human and social capital. Economic Modelling, [online] 60, pp.448-461. Available at: <https://www.sciencedirect.com/science/article/abs/pii/S0264999316303248>. https://doi.org/ 10.1016/j.econmod.2016.09.005

Bergh, A. and Bjørnskov, C., 2014. Trust, welfare states and income equality: Sorting out the causality. European Journal of Political, [online] 35, pp.183-199. Available at: <http://dx.doi.org/10.1016/ j.ejpoleco.2014.06.002 >. https://doi.org/10.1016/j.ejpoleco.2014.06.002

Blundell, R. and Bond, S., 2000. GMM Estimation with persistent panel data: an application to production functions. Econometric Reviews, [online] 19(3), pp.321-340. Available at: <http://www.jstor.org/ stable/2297968 >. https://doi.org/10.1080/07474930008800475

Bolaños, N.P., Saucedo-Acosta, E.J. and Del Callejo, D., 2020. Inequality, Social Capital, and Varieties of Capitalism in Latin America. Economic Research-Ekonomska Istraživanja, [online] pp.1-20. Available at: <https://doi.org/10.1080/1331677X.2020.1844583>. https://doi.org/10.1080/1331677X.2020.1844583

Borozan, D. and Funaric, M.R., 2016. Social capital in Croatia: measurement and regional distribution. Innovation: The European Journal of Social Science Research, [online] pp.1-26. Available at: <https://www.tandfonline.com/doi/abs/10.1080/13511610.2016.1159945>.

Bowles, S. and Gintis, H., 2001. Social Capital and Community Governance. Economic Journal, [online] pp.124. Available at: <http://www.socialcapitalgateway.org/content/paper/bowles-s-gintis-h-2002-social-capitaland-community-governance-economic-journal-112-48>. https://doi.org/10.1111/1468-0297.00077

Brunie, A., 2009. Meaningful distinctions within a concept: Relational, collective, and generalized social capital. Social Science Research, [online] 38, pp.251-265. Available at: <https://www.sciencedirect.com /science/article/abs/pii/S0049089X09000076>. https://doi.org/10.1016/j.ssresearch.2009.01.005

Cañizares, M., Barroso, I. and Alfonso, K., 2004. Datos incompletos: una mirada crítica para su manejo en estudios sanitarios. Gaceta sanitaria, [online] 18(1), pp.58-63. Available at: <http://dx.doi.org/10.1016/S02139111(04)72000-2>. https://doi.org/10.1016/S0213-9111(04)72000-2

Consejo Nacional de Evaluación de la Politica de Desarrollo Social, C., 2019. BASE DE DATOS. [online] CONEVAL. Available at: <https://www.coneval.org.mx/Paginas/principal.aspx> [Accessed 20 Dec. 2019].

Dargent, E. and Muñoz, P., 2012. Perú 2011: Continuidades y Cambios en la PolítiCa sin Partidos. Revista de Ciencia Política, 32(1), pp.245-268. https://doi.org/10.4067/S0718-090X2012000100013

Departamento Administrativo Nacional de Estadística, D., 2019. Medición de la Pobreza Monetaria y Desigualdad. [online] ANDA. Available at: <http://microdatos.dane.gov.co/index.php/catalog/MICRODATOS /about_collection/27/4>.

Elgar, F.J. and Aitken, N., 2011. Income inequality, trust and homicide in 33 countries. European Journal of Public Health, [online] 21(2), pp.241-246. Available at: <https://academic.oup.com/eurpub/article /21/2/241/498070 >. https://doi.org/10.1093/eurpub/ckq068

Gallicchio, E., 2004. El desarrollo local en América Latina, Estrategia Política basada en la construcción de Capital Social. FLACSO ECUADOR, [online] (80), pp.1-24. Available at: <https://flacso.edu.ec/cite/gallicchio-e_2004_el-desarrollolocal-en-america-latina-estrategia-politica-basada-en-la-construccion-de-capital-social/>. 
Geys, B. and Murdoch, Z., 2008. How to make head or tail of 'bridging ' and ' bonding '?: addressing the methodological. The British Journal of Sociology, [online] 59(3), pp.436-452. Available at: <https://openr esearchrepository.anu.edu.au/bitstream/1885/43276/2/DP511.pdf>. https://doi.org/10.1111/j.1468-4446.2008.00202.x

Glanville, J.L., Paxton, P. and Wang, Y., 2016. Social Capital and Generosity: A Multilevel Analysis. Nonprofit and Voluntary Sector Quarterl, [online] 45(3), pp.526-547. Available at: <http://www.nber.org/papers/w23761>. https://doi.org/10.1177/0899764015591366

Güemes, M.C., 2011. Estado y capital social en América Latina: ¿En qué medida las características y comportamientos del estado explican los niveles de capital social en la región? América Latina Hoy, [online] 59, pp.91-116. Available at: <https://gredos.usal.es/bitstream/handle/10366/120677/Estado_y_capital_ social_en_America_Latin.pdf?sequence=1\&isAllowed=y>.https://doi.org/10.14201/alh.8709

Halpern, D., 2005. Social capital. Malden.

Hardy, C., 2003. Una nueva generación de reformas sociales en América Latina. Colecciòn ideas, 17.

Honaker, J. and King, G., 2010. What to Do about Missing Values in Time-Series Cross-Section Data. Midwest Political Science Association, [online] 54(2), pp.561-581. Available at: <https://www.jstor.org/stable/25652223>. https://doi.org/10.1111/j.1540-5907.2010.00447.x

Hoyman, M., Mccall, J., Paarlberg, L. and Brennan, J., 2016. Considering the Role of Social Capital for Economic Development Outcomes in. Economic Development Quartely, [online] 30(4), pp.342-357. Available at: <https://journals.sagepub.com/doi/10.1177/0891242416659135>.

Instituto Nacional de Estadistica y Geografia, I., 2019. Base de datos. [online] INEGI. Available at: $<$ https://www.inegi.org.mx/> [Accessed 6 Nov. 2019].

Intituto Nacional de Estadistica e Informatica, I., 2019. Base de datos. [online] INEl. Available at: $<$ https://www.inei.gob.pe/> [Accessed 6 Nov. 2019].

Jhonh F, H., Lara B, A., Hugh, S., Haifang, H. and Shun, W., 2017. Social Capital and Prosocial Behavior as Sources of Well Being. [online] Available at: <http://www.nber.org/papers/w23761>.

Joignant, A., 2011. The Politics of Technopols : Resources, Political Competence and Collective Leadership in Chile, 1990-2010. Journal of Latin American Studies, [online] (43), pp.517-546. Available at: <https://doi.org/10.1017/S0022216X11000423>.

Kim, M., Kim, D. and Mcneely, N.A., 2020. Race, inequality, and social capital in the U.S. The Social Science Journal, [online] 00(00), pp.1-19. Available at: <https://doi.org/10.1080/03623319.2020.1799178>.

Kliksberg, B., 1999. Capital social y cultura, claves esenciales del desarrollo. Revista de la CEPAL, [online] pp.84-101. Available at: <https://www.cepal.org/es/publicaciones/12190-capital-social-cultura-clavesesenciales-desarrollo>. https://doi.org/10.18356/285f3940-es

Knack, S. and Keefer, P., 1997. Does Social Capital Have an Economic Payoff? A Cross-Country. Quarterly Journal of Economics, [online] 112(4), pp.1251-1288. Available at: <http://www.jstor.org/stable/2951271 Accessed:>. https://doi.org/10.1162/003355300555475

Kocher, M.G. and Martinsson, P., 2016. Strong, bold, and kind: self-control and cooperation in social dilemmas. Experimental Economics. https://doi.org/10.1007/s10683-015-9475-7

Latinobarometro, L., 2019. Base de datos. [online] Latinobarometro. Available at: <http://www.latin obarometro.org/lat.jsp>.

Lee, W.C. and Law, S.H., 2017. Roles of Formal Institutions and Social Capital in Innovation Activities : A CrossCountry Analysis. Global Economic Review, [online] pp.203-231. Available at: <https://www.tandf online.com/doi/abs/10.1080/1226508X.2017.1292859>.

Leigh, A., Duncan, M., Frijters, P. and Hopkins, D., 2006. Trust , Inequality and Ethnic Heterogeneity. [online] 82(258), pp.268-280. Available at: <https://onlinelibrary.wiley.com/doi/abs/10.1111/j.1475-4932.2006.00339.x>.

Milanese, J.P., 2011. Participación, éxito y prioridad. Un análisis macro de los equilibrios en las relaciones entre los poderes ejecutivo y legislativo en Colombia, 2002-2006. Revista CS, [online] pp.111-145. Available at: <https://www.redalyc.org/pdf/4763/476348371004.pdf>. https://doi.org/10.18046/recs.i8.1131

Ministerio de Desarrollo Social y de la Familia, M., 2019. Base de datos. [online] MDSF. Available at: <http://observatorio.ministeriodesarrollosocial.gob.cl/casen/casen_obj.php> [Accessed 6 Nov. 2019].

Organization for Economic Co-operation and Development, O., 2001. The Well- Being of Nations. The Role of Human And Social Capital. [online] OECD. OECD. Available at: <http://www.oecd.org/site/worldforum/33703702.pdf>.

Organization for Economic Co-operation and Development, O., 2019. Base de datos. [online] OECD. Available at: <https://www.oecd.org/> [Accessed 19 Oct. 2019]. 
Paarlberg, L.E., Hoyman, M. and McCall, J., 2017. Heterogeneity, Income Inequality, and Social Capital: A New Perspective* ${ }^{*}$ Social Science Quarterly, [online] (1993). Available at: <http://doi.wiley.com/10.1111/ssqu.12454>.

Pletzer, J.L., Balliet, D., Joireman, J., Kuhlman, D.M., Voelpel, S.C. and Lange, P.A.., 2018. Social Value Orientation, Expectations, and Cooperation in Social Dilemmas: A Meta-analysis. European Journal of Personality, [online] 83, pp.62-83. Available at: <https://journals.sagepub.com/doi/full/10.1002/per.2139>.

Putnam, R., 2000. Bowling Alone: America's Declining Social Capital. New York: Simon \& Schuster paperbacks. https://doi.org/10.1007/978-1-349-62397-6_12

Putnam, R.D., 1993. Making democracy work: Civic traditions in moderm Italy. United Kidgdom: Princeton University Press. https://doi.org/10.2307/j.ctt7s8r7

Ram, R., 2012. Social Capital and Income Inequality in the United States. International Atlantic Economic Society, [online] pp.89-91. Available at: <https://link.springer.com/article/10.1007\%2Fs11293-012-9342-2>.

Robison, L.J., Siles, M.E. and Schmid, A., 2003. El capital social y la reducción de la pobreza: hacia un paradigma maduro. In: Capital social y reducción de la pobreza en América Latina y el Caribe : en busca de un nuevo paradigma. Santiago de Chile: Comisión Económica para América Latina y el Caribe Universidad, pp.51-113.

Roodman, D., 2009. How to do xtabond2: An introduction to difference and system GMM in Stata. The Stata Journal, [online] 9(1), pp.86-136. Available at: <https://journals.sagepub.com/doi/pdf/10.1177/1536867X0900900106>.

Rothstein, B. and Uslaner, E.M., 2006. All for All: Equality, Corruption, and Social Trust. World Politics, [online] 58(01), pp.41-72. Available at: <http://www.journals.cambridge.org/abstract_S004388710001889X >. https://doi.org/10.1353/wp.2006.0022

Schaik, T. Van, 2002. Social Capital in the European Values Study Surveys Social. En Documento nacional preparado para la conferencia internacional OECD-ONS sobre Medición del capital social de Londres, [online] pp.25-27. Available at: <https://pure.uvt.nl/ws/portalfiles/portal/491596/2381883.pdf>.

Sorenson, O. and Rogan, M., 2014. ( When ) Do Organizations Have Social Capital ? Annual Review ofSociology, 40, pp.261-280. https://doi.org/10.1146/annurev-soc-071913-043222

Stephany, F., 2017. Who are Your Joneses? Socio-Specific Income Inequality and Trust. Social Indicators Research, [online] 134(3), pp.877-898. Available at: <https://link.springer.com/article/10.1007/s11205-016-1460-9>.

Stiglitz, J.E., 2012. El precio de la desigualdad. El 1\% tiene lo que el 99\% necesita. Taurus.

The World Bank, W., 2020. Data base. [online] GINI index (World Bank estimate. Available at: $<$ https://data.worldbank.org/indicator/SI.POV.GINI>.

Wang, G. and Lu, Q., 2016. Influence of social capital on farmer household income gap: total effect and structural effect structural effect. Chinese Journal of Population Resourses and EnviroNment, [online] 14(1), pp.30-37. Available at: <http://dx.doi.org/10.1080/10042857.2016.1149297>.

Wilkinson, R. and Pickett, K., 2009. Desigualdad. Un análisis de la (in)felicidad colectiva. Turner, publications.

Woolcock, M., 2010. The Rise and Routinization of Social Capital , 1988 - 2008. Annual Review ofPolitical Science, [online] pp.469-487. Available at: <https://www.annualreviews.org/doi/full/10.1146/ annurev.polisci.031108.094151>. 